\title{
The Level of Financial Literacy: A Lesson from the Village Community in Toba Lake, North Sumatera, Indonesia
}

\author{
Handriyani Dwilita, SE.,MSi \\ Accounting Department, Faculty of Economics \& Business \\ Universitas Pembangunan Panca Budi, Medan, North Sumatera, Indonesia \\ Email: handriyanidwilitia@dosen.pancabudi.ac.id \\ Pipit Buana Sari, SE., MM (Corresponding Author) \\ Accounting Department, Faculty of Economics \& Business \\ Universitas Pembangunan Panca Budi, Medan , North Sumatera, Indonesia \\ E-mail: pipitbuana@dosen.pancabudi.ac.id
}

\section{Devita Elyana SE}

Accounting Department, Faculty of Economics \& Business

Universitas Pembangunan Panca Budi, Medan , North Sumatera, Indonesia

Email: elyanadevita@gmail.com

Received: January 26, 2017 Accepted: February 18, 2017 Published: March 20, 2017 doi:10.5296/ijafr.v7i1.10652 URL: http://dx.doi.org/10.5296/ijafr.v7i1.10652

\begin{abstract}
The research purpose is to investigate the level of financial literacy of village community "Dosroha". The method used in this research is a descriptive method. Data Process using application software SPSS version 17. The result shows that the level of knowledge of financial literacy Dosroha village communities, including in the category is sixty until eighty percent. Based on the financial behavior that desired not appropriate and does not increase consistently. The characteristics of respondents with relatively high financial literacy are the society of female, while the community that has a low financial literacy level is the male.
\end{abstract}

Keywords: Literacy, Personal Financial, Financial Behavior 


\section{Macrothink}

\section{Introduction}

\subsection{Background}

The success of the construction was marked by the creation of a stable financial system and creates benefits for all layers of the society. In this case, financial institutions play a major role through the intermediary function to promote economic growth, revenue balancing, poverty reduction and achievement of the financial system stability. Only the financial industry was growing immediate may not necessarily be accompanied by sufficient financial access, even though the access to financial services is an essential condition of the wider community involvement in the economic system. The accessing of financial services is the issues correlating to the side of the public as consumers and financial institutions view as the manufacturer. The requires of the formulation of a multi-dimensional approach to improving community access to financial services. The Inclusive of financial activities to become one of the important agenda in the international world. In Indonesia, itself inclusive financial has become the priority of the government of Indonesia. In addition to the inclusive financial government also make financial literacy as a priority for financial literacy, including the finance section inclusive. It proved with the launching of the program financial literacy in 2013 by the Financial Services Authority.

Financial literacy is a series of processes or activities to enhance the knowledge, skills and consumer confidence and the wider community that they can manage their personal finances with better. In the National Strategy for Financial Literacy Financial Services Authority proposed three pillars of financial literacy: Pillars of education and the national campaign financial literacy, the pillars of strengthening the infrastructure of financial literacy and the pillars of the development of financial products and services. The pillars of Financial Literacy reflect policy strategy to increase the level of knowledge society about the financial products and services. Financial literacy aims to provide an understanding of the financial sector in society. Financial Literacy must also define as a series of process, or activities to enhance the knowledge, skill and faith communities, they can manage their personal finance is beneficial. Financial literacy help to improve the quality of the service of finance to contribute the economic and development growth a state.

The lack of financial literacy can lead to low access to financial institutions and inhibits the prosperity, as according to a member of the Commissioner of Financial Services Authority, Soetiono, an extensive access to the financial system structured leases micro, poor communities and women and household productive, then can reduce income differences among the community (Kompas,13 June 2012). The more complex financial products are the main reason for the community to have sufficient financial literacy. There are times when the low-income levels do not only cause financial difficulties, but it can also be caused by an error in the financial planning for financial literacy is required adequate. So with the right management is of course supported by high financial literacy, then the rank of life is expected to increase. The applies to every income levels a person without proper management; financial security would be difficult to achieve.

The communities living in villages or remote areas is a real target for financial institutions to 
introduce the financial literacy. One of these is the village community in sub-district Simanindo Dosroha Samosir, Toba Lake North Sumatra.Toba Lake is one of the ten national tourism areas that will be prioritized to tending. The Government through the Presidential Bylaws Regulations No. 3, 2016 regarding the acceleration of the implementation of the national strategic projects, determined to address the Toba Lake as one of the tourism destination international standard. "Dosroha " village, Simanindo could near in the subdistrict "Pangururan" proximate to where the village "Dosroha" is the result of the merger of three villages namely "Sidabagas" Village, the Village of "Tanda Rabun", and the village of "Pinto". The picture of the villagers "Dosroha" mostly farmers were enterprising, civil workers, and another public education level and still relatively low and allows. still image financial knowledge of the banking and finance inclusive including financial literacy. Financial literacy can help the community in managing personal financial resources effectively for the welfare of his life, and support people have access to the financial system.

Based on the phenomenon, the authors are interested in exploring the research about " THE LEVEL OF FINANCIAL LITERACY: LESSONS FROM THE VILLAGE COMMUNITY IN TOBA LAKE, NORTH SUMATERA, INDONESIA."

\subsection{Identification and Formulation of the problems}

Based on the above background,the formulation of the problem in this research as follows: (1) How the level of financial literacy community especially the villagers Dosha to prepare Toba Lake as a tourism destination of international standard?; (2) How description of personal finance village communities "Dosroha " to prepare Toba Lake as a tourism destination of international standard?; (3) How the image from financial behavior "Dosroha" village communities to prepare Toba Lake as a tourism destination of international standard?

\section{Literature Review}

\subsection{Financial Literacy}

According to Bhushan and Medury (2013) "Financial literacy is the ability to make evaluation information and take effective decisions about the use and management of money." Financial literacy is the combination of the ability of the individual in the manage finance, knowledge of finance and the behavior of persons who are related to money. Based on these definitions, it can be concluded that financial literacy is the knowledge of the individual about finance and the ability of the individual to make an effective financial decision. The definition of financial literacy according to the Masons \& Wilson (in Krisna, et.al, 2010) is the ability of a person to get, understand and evaluate relevant information to decision-making to understand the financial consequences in its wake. According to Hutson, (2010). Financial literacy is the ability of a person with the knowledge and skills in managing financial resources effectively for welfare in the future".

\subsection{Factors affect the Financial Literacy}

The level of financial literacy is owned by everyone is different. The difference level of Financial Literacy caused a significant difference between the individual one with the other in 


\section{I Macrothink}

International Journal of Accounting and Financial Reporting

ISSN 2162-3082

2017, Vol. 7, No. 1

gathering the assets both short or long term. Huston (2010) explained that the factors such as the habit, economic, family peers, communities, and institutions might have an impact on the financial habits "financial behavior" or someone has financial literacy when a person has the knowledge and ability to apply the knowledge. Now Chiara Monticone (2010) explained that the level of financial literacy someone influenced by Demographic characteristics, family background, wealth and time preference. While Angelo Capuano and Ian Ramsay (2011) explained that personal factors, social and economic could affect the financial literacy and financial behavior a person.

\subsection{The level of Financial Literacy}

The level of financial literacy divided into four parts, namely:

1. Well Literate, They have the knowledge and beliefs about financial services institutions and financial products and services, including features, benefits and risks, rights and obligations related to the product and financial services, and have skills in the use of financial products and services.

2. Suff Literate, They have the knowledge and beliefs about financial services institutions and financial products and services, including features, benefits and risks, rights and obligations related to financial products and services.

3. Less Literate, They have the knowledge of the financial services and financial products and services.

4. Not Literate, They do not have the knowledge and beliefs about financial services institutions and financial products and services and does not have the necessary skills in the use of financial products and services defined as the knowledge of the concepts of financial (Lusardi, 2008).

Personal financial includes basic knowledge of personal finances (basic personal finance), knowledge about credit and debt knowledge of savings. In the basic, Personal Finance includes a variety of basic understanding of the person in a financial system as a simple interest calculation, compound interest, inflation, time value and liquidity assets.

\subsection{Financial Behavior}

Financial Behavior related to how a person treats, manage and use the existing financial resources it.Individuals who have financial behavior that is responsible for tending to be effective in the managing of the money that possessed such as make budget, save money and control the shopping and the payment obligations on time.

\subsection{Inclusive Financial.}

Inclusive financial is defined as the right of every person to have access and full service from financial institutions promptly, comfortable informative and affordable, with full respect for the dignity and dignity. Financial services are available for all segments of society with particular attention to the poor and the needy productive, migrant workers and the population in remote areas. 


\subsection{Inclusive of Finance Goal.}

The inclusive of finance goal is to achieve economic prosperity through poverty reduction, revenue distribution and stability of the financial system in Indonesia was cushioned reach the financial system can be accessed by all layers of the society.

\section{Research Method}

The research uses the descriptive approach .Data used is the primary data by distributing the questionnaire to the respondents. The population is people living in villages Sub-district Simanindo "Dosroha" Samosir Toba Lake North Sumatra to 831 inhabitants. Sample selection is made by the method of sampling forcible entry. By using equations Slovin, resulting in the number of samples of 270 but due to time constraints then samples obtained only 130. Now, this research consists of 2 free variables namely personal finance (X1) and financial behavior (X2), and a bound variable is the level of literacy (Y). In the spread of the questioner, every of each variable is divided into 15 point declaration of personal finance and 15 questions details about financial behavior. The details of the statement related to the variable operational will be explained in the table below;

Table 3.3: Operational Variables

\begin{tabular}{|c|c|c|c|}
\hline Variables & Indicator & Description & Scale \\
\hline $\begin{array}{l}\text { Personal } \\
\text { Finance } \\
\text { (X1) }\end{array}$ & $\begin{array}{l}\text { - Knowledge basis of personal finance } \\
\text {-Income } \\
\text { - \&deposits Loans } \\
\text { - Savings Account } \\
\text {-Insurance } \\
\text { - Debt } \\
\text { - Credit Cards }\end{array}$ & $\begin{array}{l}\text { Personal Finance is the } \\
\text { knowledge of the concepts of } \\
\text { finance. (Nababan and Sadalia, } \\
\text { 2012) }\end{array}$ & Likert \\
\hline $\begin{array}{l}\text { Financial } \\
\text { Behavior } \\
(\mathrm{X} 2)\end{array}$ & $\begin{array}{l}\text {-Create a personal financial } \\
\quad \text { budget/family } \\
\text {-Control personal spending } \\
\text { - Save money } \\
\text { - Record daily spending } \\
\text {-Pay obligation } \\
\text {-The monthly Audit }\end{array}$ & $\begin{array}{l}\text { Behavior finance related to how a } \\
\text { person treats, manage and use } \\
\text { financial resources that are with } \\
\text { him. (Nababan and Sadalia, 2012) }\end{array}$ & Likert \\
\hline $\begin{array}{l}\text { Financial } \\
\text { Literacy } \\
(\mathrm{Y})\end{array}$ & $\begin{array}{l}\text {-Knowledge of Finance } \\
\text {-The ability to communicate about the } \\
\text { concept of Finance } \\
\text {-The ability to manage personal } \\
\text { finances/ Family } \\
\text {-The ability to make financial } \\
\text { decisions } \\
\text {-Confidence in doing future financial } \\
\text { planning }\end{array}$ & $\begin{array}{l}\text { Financial literacy is the ability to } \\
\text { read, analyzing, manage and } \\
\text { communicate about personal } \\
\text { financial conditions that will } \\
\text { affect the material welfare (Farah } \\
\text { and Reza, 2015) }\end{array}$ & Likert \\
\hline
\end{tabular}




\section{$\Lambda$ Macrothink}

Source: Previous Research

\section{Discussion}

The results of the survey the level of Personal Financial Overall

Table 4.1.The entire Level of Personal Financial

\begin{tabular}{|l|l|l|l|l|l|}
\hline $\mathrm{N}$ & Min (\%) & Max (\%) & Mean (\%) & Median (\%) & $\begin{array}{l}\text { Standard } \\
\text { deviation }\end{array}$ \\
\hline 130 & 53,33 & 100 & 76 & 80 & 11,63 \\
\hline
\end{tabular}

Source: Primary Data processing result, 2016

It could be showed in Table 1. That shows quite a lot of respondents who have the level of personal finance (knowledge of finance) the relative is considered from the value of the minimum 53,33\%. Most respondents were distributed near the median (80\%). Average correct answers are grouped into three categories namely low $(<60 \%)$, is $(60 \%<80 \%)$, and high $(>80 \%)$ to facilitate research. This method refers to the previous research by Chen and Volpe (1998) where the correct answer is calculated and percenta ge against the number of all the questions. The number and percentage of respondents based on the three categories can be seen in Table 2;

Table 4.2 Level of Personal Financial Literacy

\begin{tabular}{|l|l|l|}
\hline Category & The number of & The percentage of \\
\hline Low $(<60 \%)$ & 5 & 3.8 \\
\hline Medium $(60<80)$ & 77 & Measured at 59.2 \\
\hline High $(>80)$ & 48 & 37,0 \\
\hline The Total & 130 & 100 \\
\hline
\end{tabular}

Source: Primary Data processing result, 2016

Based on the table above can be explained: $3.8 \%$ community is in a low category, measured at 59.2 percent in the category of being, and 37,0\% that have personal finance (knowledge of finance) with a high level. The average personal finance the villagers "Dosroha" reached 76 percent fall into the category of being. That indicates the average of respondents able to answer more than half of the questions from all the questions

\subsection{Description of the characteristics of respondents}

Based on the table 3 that could be recognized the level of personal finance in "Dosroha" 
village communities based on the characteristics which have been assigned the previously gender, age level of education, employment and monthly income.

Table 4.3: Characteristics of respondents based on the Demographic Background

\begin{tabular}{|c|c|c|c|c|}
\hline Characteristcs & $\mathrm{N}$ & $\begin{array}{l}\text { Average level } \\
\text { of personal } \\
\text { finance }(100 \%)\end{array}$ & $\begin{array}{l}\text { Median } \\
(100 \%)\end{array}$ & $\begin{array}{l}\text { Standard } \\
\text { deviation } \\
(100 \%)\end{array}$ \\
\hline \multicolumn{5}{|l|}{ Gender } \\
\hline 1. Male & 54 & $75 \%$ & $80 \%$ & $11 \%$ \\
\hline 2. Female & 76 & $78 \%$ & $80 \%$ & $13 \%$ \\
\hline \multicolumn{5}{|l|}{ Age } \\
\hline 1. 19 Years & 1 & $86,67 \%$ & - & - \\
\hline 2. 20-24 years & 7 & $80 \%$ & $80 \%$ & 0 percent \\
\hline 3. 25-29 years & 11 & $75 \%$ & $80 \%$ & $10 \%$ \\
\hline 4. $30-34$ years & 16 & $80 \%$ & $80 \%$ & 0 percent \\
\hline 5. $35-39$ years & 33 & $74 \%$ & $80 \%$ & $10 \%$ \\
\hline 6. 40-44 years & 28 & $76 \%$ & $80 \%$ & $17 \%$ \\
\hline 7. 45-49 years & 21 & $80 \%$ & $80 \%$ & $13 \%$ \\
\hline 8. 50-54 years & 11 & $70 \%$ & $70 \%$ & $14 \%$ \\
\hline 9. 55-59 years & 2 & $60 \%$ & $60 \%$ & 5 percent \\
\hline \multicolumn{5}{|l|}{ The level of Education } \\
\hline 1. Junior High School & 40 & $66 \%$ & $60 \%$ & $10 \%$ \\
\hline 2. Senior High School & 67 & $82 \%$ & $80 \%$ & 8 percent \\
\hline 3. Diploma & 2 & $90 \%$ & $90 \%$ & $14 \%$ \\
\hline 4. Graduate & 2 & $70 \%$ & $70 \%$ & $12 \%$ \\
\hline \multicolumn{5}{|l|}{ The Occupation } \\
\hline 1. Farmers/Fishermen & 51 & $73 \%$ & $80 \%$ & $14 \%$ \\
\hline 2. PNS & 26 & $78 \%$ & $80 \%$ & 7 percent \\
\hline 3. Self-employed & 28 & $76 \%$ & $80 \%$ & 8 percent \\
\hline
\end{tabular}




\begin{tabular}{|l|l|l|l|l|}
\hline 4. And others & 25 & $80 \%$ & $80 \%$ & $13 \%$ \\
\hline Income level & & & & \\
1. $\quad<$ Rp 1.000.000 & 8 & $73 \%$ & $80 \%$ & $12 \%$ \\
2. Rp1.000.000, < Rp3.000 & 106 & $77 \%$ & $80 \%$ & $11 \%$ \\
$\quad .000$ & 16 & $60 \%$ & $60 \%$ & $12 \%$ \\
3. >Rp. 3.000.000 & & & & \\
\hline
\end{tabular}

Source: Primary Data processing result, 2016

\section{2: The results of the survey for the Financial Behavior}

In the research, the respondents asked about how often they perform some behavior that related with personal finance. This method is in line with the previous research (Xiao, et.al., 2007) where each statement gave the scale of "never," "rarely/sometimes," and "always/ often."Based on the results of the survey for the financial behavior shows the following result:

Table 4.4: Frequency of daily behavior related to personal finance

\begin{tabular}{|l|l|l|l|l|}
\hline No & Question & Never & $\begin{array}{l}\text { Rarel } \\
\mathbf{y}\end{array}$ & $\begin{array}{l}\text { Always } \\
\text { / often }\end{array}$ \\
\hline 1 & Make a note of spending and income every day & 65,4 & 27,7 & 6,90 \\
\hline 2 & Make a note of income or revenue every day. & 68.5 & 24,6 & 6.9 \\
\hline 3 & Attempting to control the expenses or shopping & 29.2 & 13.1 & $\begin{array}{l}57 \\
57.7\end{array}$ \\
\hline 4 & $\begin{array}{l}\text { When there is a discount, strive not to become willing to } \\
\text { purchase the product when the product is not needed. }\end{array}$ & 56.9 & 10 & 33.1 \\
\hline 5 & Make financial plans for the future & 54,6 & 12.3 & 33.1 \\
\hline 6 & Pay electricity bills, water, and timely phone & 5.4 & 20.8 & 73,8 \\
\hline 7 & Pay for the cost of school every month on time & 25.4 & 19.2 & 55,4 \\
\hline 8 & At the end of each month always adjust note income & 66, & 23,1 & 10 \\
\hline
\end{tabular}




\begin{tabular}{|c|c|c|c|c|}
\hline & between planned with that has been obtained & 9 & & \\
\hline 9 & $\begin{array}{l}\text { At the end of each month always adjust note } \\
\text { expenditures between planned with that has been issued }\end{array}$ & 69,2 & 23,1 & 7.7 \\
\hline 10 & $\begin{array}{l}\text { At the end of each month always adjust note the } \\
\text { expenses with the income }\end{array}$ & 22.3 & 65,4 & 12.3 \\
\hline 11 & Always set aside revenue for the unexpected expenses & 5.4 & 36,9 & By 57.7 \\
\hline 12 & $\begin{array}{l}\text { Compare the prices between stores before decide to } \\
\text { purchase }\end{array}$ & 0.8 & 16.1 & 83,1 \\
\hline 13 & $\begin{array}{l}\text { Do the consideration before making a purchase of a } \\
\text { product or service }\end{array}$ & 1.5 & 7.7 & 90.8 \\
\hline 14 & Spend revenues for saving & 0.8 & 30.7 & 68.5 \\
\hline 15 & Not excessive spending (not wasteful) & 3.07 & 9.2 & 87,7 \\
\hline
\end{tabular}

Source: Data Processing descriptive statistics, 2016

\subsection{Financial analysis Behavior based on Financial Literacy}

Researchers divided the level of financial literacy of respondents are classified into two parts based on the median to see the relevance of personal finance and financial behavior. From the primary data processing results obtained 5 the respondents have the level of personal finance under the median $(<80 \%)$ and 125 the respondents have the level of financial behavior above median $(>80 \%)$. Based on the results of the tests performed can be examined the comparison of the number of respondents with financial literacy level that is relatively low and relatively high. It can be seen that the financial behavior respondents not by what is expected or not consistent.

The table 4.5 below shows the comparison of the behavior between these two groups of respondents with financial literacy is relatively low and relatively high

\begin{tabular}{|c|l|l|l|l|l|l|l|}
\hline \multirow{2}{*}{} & \multirow{2}{*}{ Financial Behavior } & \multicolumn{5}{|c|}{ Financial Literacy } \\
\cline { 3 - 8 } & & \multicolumn{3}{|c|}{ Relatively Low } & \multicolumn{3}{c|}{ Relatively High } \\
\cline { 3 - 8 } & & Never & Rarely & Always & Never & Rarely & Always \\
\hline 1 & $\begin{array}{l}\text { Make note everyone involved- } \\
\text { superficial and income every day. }\end{array}$ & $40 \%$ & 1 & 0 & 81 & 35 & 9 \\
& & $20 \%$ & 0 & $64,80 \%$ & $28 \%$ & $7,20 \%$ \\
\hline
\end{tabular}




\begin{tabular}{|c|c|c|c|c|c|c|c|}
\hline & & & & percent & & & \\
\hline 2 & $\begin{array}{l}\text { Make note lands- estates or income } \\
\text { every day }\end{array}$ & $\begin{array}{l}4 \\
80 \%\end{array}$ & $\begin{array}{l}1 \\
20 \%\end{array}$ & $\begin{array}{l}0 \\
0 \\
\text { percent }\end{array}$ & $\begin{array}{l}82 \\
65,6 \%\end{array}$ & $\begin{array}{l}34 \\
27.2 \%\end{array}$ & $\begin{array}{l}9 \\
7.2\end{array}$ \\
\hline 3 & $\begin{array}{l}\text { Attempting to control the expenses } \\
\text { or shopping }\end{array}$ & $\begin{array}{l}2 \\
40 \%\end{array}$ & $\begin{array}{l}1 \\
20 \%\end{array}$ & $\begin{array}{l}2 \\
40 \%\end{array}$ & $\begin{array}{l}39 \\
21,2 \%\end{array}$ & $\begin{array}{l}14 \\
11.2 \%\end{array}$ & $\begin{array}{l}72 \\
57,6 \%\end{array}$ \\
\hline 4 & $\begin{array}{l}\text { When there is a discount, strive not } \\
\text { to become willing to purchase the } \\
\text { product when the product is not } \\
\text { needed. }\end{array}$ & $\begin{array}{l}5 \\
100 \%\end{array}$ & $\begin{array}{l}0 \\
0 \\
\text { percent }\end{array}$ & $\begin{array}{l}0 \\
0 \\
\text { percent }\end{array}$ & $\begin{array}{l}68 \\
54,4 \%\end{array}$ & $\begin{array}{l}13 \\
10.4 \%\end{array}$ & $\begin{array}{l}44 \\
35.2 \\
\text { per\% }\end{array}$ \\
\hline 5 & Make financial plans for the future & $\begin{array}{l}4 \\
80 \%\end{array}$ & $\begin{array}{l}1 \\
20 \%\end{array}$ & $\begin{array}{l}0 \\
0 \\
\text { percent }\end{array}$ & $\begin{array}{l}74 \\
\text { Measured } \\
\text { at } 59.2 \%\end{array}$ & $\begin{array}{l}16 \\
12.8 \%\end{array}$ & $\begin{array}{l}35 \\
28 \%\end{array}$ \\
\hline 6 & $\begin{array}{l}\text { Pay electricity bills, water, and } \\
\text { timely phone }\end{array}$ & $\begin{array}{l}0 \\
0 \text { percent }\end{array}$ & $\begin{array}{l}2 \\
40 \% \\
\end{array}$ & $\begin{array}{l}3 \\
60 \% \\
\end{array}$ & $\begin{array}{l}10 \\
8 \text { percent }\end{array}$ & $\begin{array}{l}43 \\
34.4 \% \\
\end{array}$ & $\begin{array}{l}92 \\
73,6 \%\end{array}$ \\
\hline 7 & $\begin{array}{l}\text { Pay for the cost of school every } \\
\text { month on time }\end{array}$ & $\begin{array}{l}1 \\
20 \%\end{array}$ & $\begin{array}{l}2 \\
40 \%\end{array}$ & $\begin{array}{l}2 \\
40 \%\end{array}$ & $\begin{array}{l}24 \\
19.2 \%\end{array}$ & $\begin{array}{l}22 \\
17.6 \%\end{array}$ & $\begin{array}{l}79 \\
63.2 \%\end{array}$ \\
\hline 8 & $\begin{array}{l}\text { At the end of each month always } \\
\text { adjust note income between } \\
\text { planned with that has been obtained }\end{array}$ & $\begin{array}{l}5 \\
100 \%\end{array}$ & $\begin{array}{l}0 \\
0 \\
\text { percent }\end{array}$ & $\begin{array}{l}0 \\
0 \\
\text { percent }\end{array}$ & $\begin{array}{l}78 \\
62.4 \%\end{array}$ & $\begin{array}{l}31 \\
24.8 \%\end{array}$ & $\begin{array}{l}16 \\
12.8 \%\end{array}$ \\
\hline 9 & $\begin{array}{l}\text { At the end of each month always } \\
\text { adjust note expenditures between } \\
\text { planned with that has been issued }\end{array}$ & $\begin{array}{l}5 \\
100 \%\end{array}$ & $\begin{array}{l}0 \\
0 \\
\text { percent }\end{array}$ & $\begin{array}{l}0 \\
0 \\
\text { percent }\end{array}$ & $\begin{array}{l}83 \\
66,4 \%\end{array}$ & $\begin{array}{l}30 \\
24 \%\end{array}$ & $\begin{array}{l}12 \\
9.6 \%\end{array}$ \\
\hline 10 & $\begin{array}{l}\text { At the end of each month always } \\
\text { adjust spending notes with pen- } \\
\text { acquired traits (income) }\end{array}$ & $\begin{array}{l}5 \\
100 \%\end{array}$ & $\begin{array}{l}0 \\
0 \\
\text { percent }\end{array}$ & $\begin{array}{l}0 \\
0 \\
\text { percent }\end{array}$ & $\begin{array}{l}81 \\
64,8 \%\end{array}$ & $\begin{array}{l}30 \\
24 \%\end{array}$ & $\begin{array}{l}14 \\
11.2 \%\end{array}$ \\
\hline 11 & $\begin{array}{l}\text { Always set aside revenue for } \\
\text { everyone involved in an outer with } \\
\text { earnings (income) }\end{array}$ & $\begin{array}{l}0 \\
0 \text { percent }\end{array}$ & $\begin{array}{l}4 \\
80 \%\end{array}$ & $\begin{array}{l}1 \\
20 \%\end{array}$ & $\begin{array}{l}39 \\
21,2 \%\end{array}$ & $\begin{array}{l}7 \\
5.6 \%\end{array}$ & $\begin{array}{l}79 \\
63.2 \%\end{array}$ \\
\hline 12 & $\begin{array}{l}\text { Compare the prices between stores } \\
\text { before decide to purchase }\end{array}$ & $\begin{array}{l}0 \\
0 \text { percent }\end{array}$ & $\begin{array}{l}1 \\
20 \%\end{array}$ & $\begin{array}{l}4 \\
80 \%\end{array}$ & $\begin{array}{l}4 \\
3.2 \%\end{array}$ & $\begin{array}{l}8 \\
14.4 \%\end{array}$ & $\begin{array}{l}103 \\
82,4 \%\end{array}$ \\
\hline 13 & $\begin{array}{l}\text { Do the consideration before making } \\
\text { a purchase of a product or service. }\end{array}$ & $\begin{array}{l}0 \\
0 \text { percent }\end{array}$ & $\begin{array}{l}0 \\
0 \\
\text { percent }\end{array}$ & $\begin{array}{l}5 \\
100 \%\end{array}$ & $\begin{array}{l}4 \\
3.2 \%\end{array}$ & $\begin{array}{l}11 \\
8.8 \%\end{array}$ & $\begin{array}{l}110 \\
88 \%\end{array}$ \\
\hline 14 & Spend revenues for saving & $\begin{array}{l}0 \\
0 \text { percent }\end{array}$ & $\begin{array}{l}3 \\
60 \% \\
\end{array}$ & $\begin{array}{l}2 \\
40 \% \\
\end{array}$ & $\begin{array}{l}5 \\
4 \text { percent }\end{array}$ & $\begin{array}{l}36 \\
28,8 \%\end{array}$ & $\begin{array}{l}84 \\
67,2 \%\end{array}$ \\
\hline 15 & $\begin{array}{l}\text { Not excessive spending (not } \\
\text { wasteful) }\end{array}$ & $\begin{array}{l}0 \\
0 \text { percent }\end{array}$ & $\begin{array}{l}0 \\
0 \\
\text { percent }\end{array}$ & $\begin{array}{l}5 \\
100 \%\end{array}$ & $\begin{array}{l}7 \\
5.6 \%\end{array}$ & $\begin{array}{l}9 \\
7.2 \%\end{array}$ & $\begin{array}{l}109 \\
87.2 \%\end{array}$ \\
\hline
\end{tabular}

Source: Data Processing descriptive statistics, 2016 


\section{MIMacrothink}

International Journal of Accounting and Financial Reporting ISSN 2162-3082

Financial behavior does not consistent can be caused or influenced by the environment and how to socialize, habit factors, psychological factors and other factors that are not included in this research. This research proves that the level of knowledge of the community about financial literacy is relative. This research in line with the research Ms. Anastasia Sri Medari and Suramaya Suci and the research of Farah Margaretha and Reza Arief Pambudhi proving that gender, age affect financial literacy a person. Research also in line with the research Darman Nababan and Isfenti also prove personal finance and financial behavior are the factors that influence the financial literacy of individual.

\section{Conclusions and Recommendations}

\subsection{Conclusion}

1. The average respondents $(80 \%)$ is able to answer the questions related to the personal finance (personal finance). The level of knowledge of financial literacy village community Sub-district Simanindo "Dosroha" Samosir Toba Lake North Sumatra including in the category is $(60-80 \%)$,

2. The characteristics of respondents with relatively high financial literacy is a society with gender women, 19 years old, with diploma level, work in the category of other and have the income of Rp 1.000.000 < Rp 3.000.000 per month. While that has a low level of financial literacy is the male, 55-59 years old, with the level of education deals SMP, working as farmers/fishers with income $>$ Rp 3,000,000,

3. Financial Behavior (Financial Behavior) who desired not appropriate and does not increase consistently. That is due to the behavior of a person who was also influenced by other factors such as the environment and how to socialize, habits and other factors.

\subsection{Recommendation}

Now the advice that can be given to the results of this research are

1. It is expected that for the government and financial institutions to be more active in providing awareness about the financial institutions and the benefits of financial institutions to the community,

2. Besides that is expected to help ease the community have access to the financial system in public to better understand about financial literacy and gels in understanding the information about finance because the knowledge about finance useful for their daily life and can improve their life,

3. For further researchers are expected to make the questioner adjust the question with respondents regarding the educational background and work to know the level of financial literacy in order to give a more accurate. In addition as well as expected to do research of a kind in the areas that have not been challenged banking services and financial institutions.

\section{References}

Allport, GW. (1996). Psikologi Sosial Edisi 5.Jakarta: Erlangga.

Arikunto, S. (2002). P rosedur Penelitian Suatu Pendekatan Praktik. Jakarta: Rineka Cipta.

Arikunto, S (2010) Prosedur Penelitian. Jakarta; Reneka Cipta. 


\section{Mll Macrothink}

International Journal of Accounting and Financial Reporting ISSN 2162-3082 2017, Vol. 7, No. 1

Bhushan, P., \& Medury, Y. (2013). Financial literacy and its determinants. International Journal of Engineering, Business and Enterprise $\quad$ Applications $\quad$ (IJEBEA), 4(2), 155160.

Capuana, Angelo dan Ian Ramsay (2011). What Cause Suboptimal Financial Behaviour? An Exploration Of Financial Literacy Social Influances And Behaviour Economics.

Cude, Lawrence, Lyons, Metzger, LeJeune, Marks, dan Machtmes, (2006), College Students and Financial Literacy: What They Know and What We Need to Learn Lousiana. Eastern Family Ekonomics and Resource Management Association.

Cude, et al. (2006). Collage Student and Financial Literacy: What They Know and What We Need to Learn. Eastern Family Economic and Resource Management Association.

Hilgert, M., J. Holgart, dan S. Baverly (2003). Household Financial Management: The Connection between Knowledge and Behavior, Federal Reserve Bulletin, 309-32

Hutson, S.J .2010. Measuring Financial Literacy. Journal of Consumer Affairs Volume 44 Issue 2.

Klontz, B., Britt, S. L., Mentzer, J., \& Klontz, T. (2011). Money belifs and financial behaviors: Development of the Klontz Money Script Inventory. Journal of Financial Therapy, $2(1), 1$.

Kompas. 13 Juni 2012. Akses Masyarakat ke Sistem Keuangan Masih Rendah. Diakses $\begin{array}{lllll}\text { pada } & \text { tanggal } & 20 & \text { Desember } & 2015 .\end{array}$ http://bisniskeuangankompas.com/read/2012/06/13/13271963/Akses.Masyarakat.ke.Sistem.K euangan. Masih.Rendah.

Krishna, A., Sari, M., \& Rofaida R. (2010). Analisis Tingkat Literasi Keuangan di Kalangan Mahasiswa dan Faktor-faktor yang Mempengaruhinya - survey pada mahasiswa niversitas Pendidikan Indonesia.

Lusardi, A \& Mitchell, O. S.(2006). Financial Literacy and Planning: Implication for Retirement Wellbeing.

Lusardi, A \& Mitchell, O. S. (2008). Debt Literacy, Financial Experience, and Overindebtedness. Preliminary and Incomplete Discussion Draft.

Lusardi, A \& Mitchell, O. S. (2009). Financial Literacy: evidence and implication for financial education. Trend and issues.

Lusardi, A., \& Mitchell, O.S. (2010). Financial Literacy and Planning: Implication for Retirement Wellbeing (No. 17078) (p. 37). Massachusetts.

Margaretha, Farah dan Pambudhi, Reza Arief (2015), Tingkat Literasi Keuangan pada Mahasiswa S-1 Fakultas Ekonomi, Skripsi SI, Diakses 4 September 2015, dari http://jurnalmanajemen . petra.ac.id.

Mendari. anastasia Sri mendari. (2013). Tingkat Literasi Keuangan Dikalangan Mahasiswa STIE MUSI.

Monticone, Chiara. (2010). Financial Literacy and Financial Advice Theory and Empirical Evidenc. Diunduh pada tanggal 1910/2015, 13:26 WIB.

Nababan, Darman dan Isfenti Sadalia. (2012) Analisis Personal Financial Literacy dan Financial Behavior Mahasiswa Strata I Fakultas Ekonomi Universitas Sumatera Barat.

Ningsih, R. U., \& Rita, M. R. (2010). Financial Attitudes dan Komunikasi Keluaga Tentang Pengeluaran Uang Saku: Ditinjau dari Perbedaan Gender. 


\section{Ml Macrothink \\ International Journal of Accounting and Financial Reporting \\ ISSN 2162-3082 2017, Vol. 7, No. 1}

Pankow, D (2003). Financial Values, attitudes and goals. North Dakota State University Extension, Publiccation FS-591.

Rutoto, Sabar. (2007). Pengantar Metdologi Penelitian, FKIP: Universitas Muria Kudus.

Remund, D L. (2010). Financial Literacy Expliced, The Case for a Clearer Dedinition in a Increasingly complex Economy. Journal of Consumer Affair Volume 44 issues 2.

Sevilla, Conduelo G., et al (1993). Pengantar Metodelogi Penelitian. Jakarta: UI-Press.

Sugiyono. (2009). Metode Penelitian Kuantitatif Kualitatif dan R\&D. Bandung: Alfabet.

Sugiyono (2012). Statistika untuk Penelitian. Bandung: Alfabeta..

Syofian, Siregar. (2014). Metode Penelitian Kuantitatif. Jakarta: Kencana

Vitt, L. A., Anderson, C. A., Kent, J., \& Lyter, D. (2000). Personal finance. Washington, DC: Fannies Mea Foundation

Wagland, S P dan Taylor S, (2009). "When It Comes to Financial Literacy, Is Gender Really an Issue?", The Australasian Accounting Business and Financial Journal.

\section{Acknowledgement}

We gratefully acknowledge financial support from Universitas Pembangunan Panca Budi and we would like to gratefully and sincerely thank M. Dharma Tuah Putra Nasution for his helpful and guidance.

\section{Copyright Disclaimer}

Copyright for this article is retained by the author(s), with first publication rights granted to the journal.

This is an open-access article distributed under the terms and conditions of the Creative Commons Attribution license (http://creativecommons.org/licenses/by/3.0/). 